\title{
HEAT RESISTANCE AND VIRULENCE OF SEROVARS OF THE MYCOBACTERIUM AVIUM COMPLEX
}

\author{
M. PAVLAS \\ Veterinary Research Institute, 62132 Brno
}

Recieved June 19, 1997

Accepted January 15, 1998

\begin{abstract}
Pavlas, M.: Heat Resistance and Virulence of Serovars of the Mycobacterium avium Complex. Acta vet. Brno 1997, 66: 249-252.

Heat resistance and virulence tested in chickens were investigated in 151 strains classified with the Mycobacterium avium complex. The highest differences in heat resistance between virulent and avirulent strains were found at 2-h exposure to $60^{\circ} \mathrm{C}$. Under such conditions, $92 \%$ of avirulent strains classified with Mycobacterium intracellulare serovars 4, 8, 9 (Schaeffer 1965) were resistant. On the other hand only $4.8 \%$ of virulent strains of Mycobacterium avium subsp. avium serovars 2,3 resisted the above exposure conditions.
\end{abstract}

Mycobacterium avium complex, virulence, heat resistance

Species designated already in the past century as Bacillus tuberculosis gallinarum (Sternberg 1892), identical with Mycobacterium tuberculosis typus gallinaceus (Lehmann and Neumann 1896) and Mycobacterium tuberculosis avium (Chester 1901), are currently of greatest importance among pathogenic mycobacteria.

Mycobacterial strains with biological properties closely resembling those of $M$. avium subsp. avium (hereinafter $M$. avium) were isolated from porcine lymph nodes in the fifties of this century. These porcine strains did not induce any lesions in rabbits even after intravenous inoculation. With regard to their origin, it was recommended to classify them as a separate species Mycobacterium suis (Baumann et al. 1955). Similar strains nonvirulent in chickens were isolated several years later from human patients suffering from a tuberculosis-like disease. Pneumokoniosis was identified as a predisposing factor in the patients. The strains were isolated at the Battey State Hospital, Georgia, and were designated Mycobacterium battey accordingly (Crow et al. 1957).

The very close similarity of biochemical properties did not allow the differentiation of the above mycobacterial species. On the other hand, marked virulence of $M$. avium in birds and other animal species was a relatively reliable characteristic for distinguishing this species from $M$. intracellulare.

Comparative investigations of $M$. avium and $M$. intracellulare revealed differences in surface antigens allowing, by means of agglutination test, the identification of 2 serovars of M. avium and another 15 serovars of $M$. intracellulare (Schaeffer 1967). So far 29 serovars of the M. avium-intracellulare complex have been identified. The serovars 1,2 and 3 were considered to belong to M. avium pathogenic for birds. According to OIE (1996), the serovar 6 of $M$. intracellulare ranks with potential agents inducing avian tuberculosis. There can be no doubt that serological typification of the M. avium-intracellulare complex has become an important component epidemiological investigations. Serovar 2 is apparently the most significant of them owing to its high prevalence and virulence for poultry, other bird species and mammals, particularly swine. Serovar 3 differs from serovars 1 and 2 in its specific lipid composition and surface antigens (Marks et al. 1969). Variable virulence has been reported for serovar 1 isolated frequently from human patients. The virulence of 
individual serovars of $M$. avium is often dependent on the origin of the strain. Thus, for instance, virulence was demonstrated in $20 \%$ of human and $66 \%$ of porcine strains belonging to serovar 1, but in all porcine strains, $97 \%$ of bovine strains and $80 \%$ of human strains belonging to serovar 2. Bioassays in chickens revealed virulence in $97.3 \%$ of the 37 tested avian strains of serovars 1 and 2 (Schaeffer 1967a).

Results of differentiation between the two mycobacterial species using virulence-based tests are not always unequivocal. In such tests, the result depends, among other factors, on the inoculum size, inoculation route, and species, age and sex of birds. Virulence was often demonstrated in $M$. intracellulare serovars when inadequate methods were used. $M$. intracellulare serovars $4,5,6,8$, and 10 are regarded as facultatively pathogenic, particularly when inoculated intravenously to chickens (Meissner 1970). The most marked differences between virulent serovars of $M$ avium and $M$. intracellulare were demonstrated after intramuscular inoculation of the tested strains at a dose of $1 \mathrm{mg}$ per chicken. On the other hand, intravenous inoculation of serovar 8 at the dose of 0.1 or 1.0 $\mathrm{mg}$ per bird induced liver and sometimes also spleen lesions leading often to death in more than 50\% of chickens (Pattyn 1967; Pavlas and Patloková 1977). A very low virulence of $M$. intracellulare serovars was also demonstrated in rabbits. Arthritic lesions developed in this species 5 to 6 months after intravenous inoculation of $1 \mathrm{mg}$ of such cultures (Kovacs 1962).

Available data show that differences between $M$. avium and $M$. intracellulare consist rather in the degree of virulence than in pathogenicity. Considering the within-serovar differences in virulence, the oral inoculation recommended by several authors for biological tests should be regarded as a rather rough or pilot method. More accurate results could perhaps be obtained in tests using macrophage cultures (Coster and Engel 1970).

Some authors have recommended the use growth potential at different temperatures as a characteristic allowing the differentiation between $M$. avium and M.intracellulare (Cowan and Steel 1965). Another characteristic for the assessment of virulence of individual serovars of the $M$. avium complex might be the higher heat resistance of $M$. intracellulare as determined by the capillary method. Investigations of heat resistance of pathogenic and facultatively pathogenic atypical mycobacteria have demonstrated marked differences in the potential to survive at $60{ }^{\circ} \mathrm{C}$ (Pavlas 1989). The objective of our experiments was to assess heat resistance of $M$. avium and $M$. intracellulare and to use contingent differences as a criterion for the differentiation between virulent and avirulent serovars of the M. avium complex.

\section{Materials and Methods}

Experience and knowledge gained during our earlier investigations of heat resistance by means of the capillary method were used and a more simple method of assessment of heat resistance in Liquid Serum-Supplenmented Medium for the Culture of Mycobacteria (SEVAC. Prague) heated in a water bath to $60^{\circ} \mathrm{C}$ immediately after the inoculation of the tested strain was chosen. One drop $(0.05 \mathrm{ml})$ of a suspension of a 4- to 6-week-old culture of mycobacteria was inoculated into $5 \mathrm{ml}$ of the medium.

A set of 151 strains of the M. avium complex, including 63 strains inducing generalized tuberculosis after intramuscular inoculation in chickens and 88 strains inducing only local lesions at the inoculation site, was tested. The strains were isolated from lymph nodes or parenchymatous organs of swine in herds showing positive reactions to avian tuberculin. By means of agglutination test with sera of rabbits immunized with reference antigens (Schaeffer 1965), most of the strains avirulent for poultry were identified as serovars 4,8 or 9 (some of them reacting also with antiserum to serovar 1), while all the strains virulent for poultry were identified as serovars 2 or 3 . A uniform dose of $1 \mathrm{mg}$ of a 4- to 6-week-old mycobacterial culture homogenized in $0.5 \mathrm{ml}$ of sterile physiological saline was administered into pectoral muscles. 
Test tubes containing mycobacterial cultures in the liquid medium were exposed in a water bath to $60^{\circ} \mathrm{C}\left(1{ }^{\circ} \mathrm{C}\right)$ for $30,60,120$, or $240 \mathrm{~min}$. A fifth tube containing an unexposed culture was used as the control. After the exposure, the test tubes were cooled with running water and put into a thermostat. Growth was read after 2,4 and 8 weeks of incubation at $37^{\circ} \mathrm{C}$.

\section{Results}

A significant difference in heat resistance at $60^{\circ} \mathrm{C}$ was found between chicken-virulent and chicken-avirulent strains of the $M$. avium complex. Three $(4.8 \%)$ of the 63 virulent strains, belonging to $M$. avium serovars 2 or 3 , and $81(92 \%)$ of the 88 strains of avirulent M. intracellulare belonging to serovars 4,8 , or 9 propagated after a 120 -min exposure to $60^{\circ} \mathrm{C}$ (Table 1). No significant differences in heat resistance were found among the above $M$. intracellulare serovars.

The results demonstrate evident differences in heat resistance between virulent and avirulent serovars of the $M$. avium complex that might be used in the assessment of biological properties of atypical mycobacteria.

Table 1

Heat resistance and virulence in chickens of serovars of the Mycobacterium avium complex

\begin{tabular}{|c|c|c|c|c|c|}
\hline \multirow{3}{*}{ Serovar } & \multirow{2}{*}{ Virulence } & \multicolumn{4}{|c|}{ Number of mycobacterial strains* } \\
\cline { 3 - 6 } & & \multicolumn{3}{|c|}{ Growth after exposure to $60^{\circ} \mathrm{C}$ for } \\
\cline { 2 - 6 } & $30 \mathrm{~min}$ & $60 \mathrm{~min}$ & $120 \mathrm{~min}$ & $240 \mathrm{~min}$ \\
\hline \multirow{3}{*}{$4,8.9$} & $\begin{array}{c}88 / 0 \\
\text { I }\end{array}$ & $\begin{array}{c}88 / 0 \\
(100 / 0)\end{array}$ & $\begin{array}{c}81 / 7 \\
(100 / 0)\end{array}$ & $\begin{array}{c}8 / 80 \\
(99 / 8)\end{array}$ & $(9.1 / 90.9)$ \\
\hline \multirow{2}{*}{2.3} & $\begin{array}{c}63 / 0 \\
\text { II }\end{array}$ & $\begin{array}{c}63 / 0 \\
(100 / 0)\end{array}$ & $\begin{array}{c}3 / 60 \\
(100 / 0)\end{array}$ & $\begin{array}{c}0 / 63 \\
(4.8 / 95.2)\end{array}$ & $(0 / 100)$ \\
\hline
\end{tabular}

I - only local lesions at the inoculation site

II - lesions at the ioculation site and in parenchy matous organs

* Numbers (\%) of resistant and sensitive strains are given in numerator and denominator, respectively.

\section{Discussion}

Our experiments were based on published data on growth properties of $M$. avium and $M$. intracellulare at 22 and $45{ }^{\circ} \mathrm{C}$ (Cowan and Steel 1965; Patty $\mathrm{n}$ and Portaels 1972) and on heat resistance of atypical mycobacteria at $60,65,70$, and $75^{\circ} \mathrm{C}$. The exposure to $60^{\circ} \mathrm{C}$, found in our previous studies as the most suitable, was chosen for heat resistance tests of virulent and avirulent serovars of the $M$. avium complex.

Many characteristics common to $M$. avium and $M$. intracellulare have been revealed by means of techniques of molecular biology (Wayne et al. 1993) and it has been suggested to include the two mycobacterial species into the Mycobacterium avium complex. Irrespective of the further development in the taxonomy of $M$. avium and $M$. intracellulare, there exist differences in virulence and other biological properties among individual serovars of the two species that should be considered in the assessment of their health significance for individual animal species. 


\section{Termorezistence a virulence serovarů Mycobacterium avium complex}

Byla ověřována termorezistence 151 kmenů Mycobacterium avium complex ve srovnání s jejich virulencí hodnocenou pomocí biologických pokusů na kuřatech. Největší rozdíly $\mathrm{v}$ termorezistenci kmenů virulentních a avirulentních byly zjištěny při teplotě $60^{\circ} \mathrm{C}$ a expozici 2 hodiny. Při této teplotě a expozici bylo rezistentních $92 \%$ kmenů avirulentnních zařazených podle serotypizace (Schaeffer 1965) do skupiny Mycobacterium intracellulare, serovar 4, 8, 9. Naproti tomu z kmenů Mycobacterium avium subsp. avium (dále M. avium), serovar 2, 3 bylo odolných ke shora uvedené teplotě a expozici pouze $4,8 \%$.

\section{References}

BAUMANN, R., KREEN. E.. LIEBISCH, H. 1955: Die käsige Lymphknotenentzündung der Schweine. Wien. tierärztl. Mschr. 62: 209-215

COSTER, J. F., ENGEL, H. W. B. 1970: Distinguishing species within ,avium-battey-swine“ complex. In: Symposium o atypických mykobakteriích. KHS Plzeň, pp. 79-86

COWAN, S. T., STEEL, K. J. 1965: The Identification of Medical Bacteria. Cambridge University Press, 238 p.

CROW, H. E., KING. C. E.. SMITH. C. E., CORPE, R. F., STORGAS, I.: 1957: A limited clinical, pathologic and epidemiologic study of patients with pulmonary lesions associated with atypical acid-fast bacilli in the sputum. Am. Rev. Tuberc. 75: 199-222

CHESTER. F. D. 1901:Manual of Determinative Bacteriology. MacMillan C., New York, 212 p.

KOVACS, N. 1962: Nichtklassifizierte Mykobakterien. Zbl. Bakt. Parasitkde 184: 46-58

LEHMANN. K. B., NEUMANN, R. 1896: Atlas und Grundriss der Bakteriologie und Lehrbuch ser Speziellen bakteriologischen Diagnostik. J.F. Lehmann, München, $728 \mathrm{p}$.

MARKS, J., JENKINS, P. A.. SCHAEFFER, W. B. 1969: Identification and incidence of third type M. avium. Tubercle 53: 394-396

MEISSNER, G. 1970: Serotyp-Bestimmungen zu Mykobakterien der aviären Gruppe. Ihre mikrobiologische und epidemiologische Bedeutung, Symposium o atypických mykobakteriích, KHS Plzeň, pp. 72-78

OIE Paris 1996: Manual of standards for diagnostic tests and vaccines. 3rd Ed. OIE PAris, $723 \mathrm{p}$.

PAVLAS, M. 1991:Zdravotní význam mykobakterií v období po eliminaci tuberkulózy skotu. Stud. Pneumologica phtiseologica Cechoslov. 51: 139-153

PAVLAS, M.. PATLOKOVÁ, V. 1977: Effect of the size of inoculum and of the mode of administration of Mycobacterium intracellulare on the results of bioassay on pullets. Acta vet. Brno 46: 129-134

PATTYN. S. R. 1967: A study of group III non-chromogenic mycobacteria. Correlation of chicken virulence with other in vitro characters among 20 strains. Z. Tuberk. 1/2:127

PATTYN, S. R., PORTAELS, F. 1972: Identification and clinical significance of mycobacteria. Zbl. Bakt. Parasitkde 219: 114-140

SCHAEFFER, W. S. 1965: Serologic identification and classification of the atypical mycobacteria. by their agglutination. Am. Rev. Resp. Dis. 92: 85-93

SCHAEFFER. W. S. 1967a: Serologic identification of the atypical mycobacteria and its value in epidemiologic studies. Am. Rev. Resp. Dis. 96: 115-118

SCHAEFFER, W.S. 1967b: Type specifity of atypical mycobacteria in agglutination and antibody adsorption tests. Am. Rev. Resp. Dis. 96: 1165-1168

STERNBERG, G. M. 1892: Manual of Bacteriology. W. Wood and Co., New York, 874 p.

WAYNE. L. G., GOOD, R. C., TSANG, A., BUTLER, R., DAWSON, D., GROOTHUIS, D., GROSS, W., HAWKINS, J., KILBURN, J., KUBIN, M., SCHRODER, K. H., SILCOX, V.A., SMITH, C., THOREL, M.F., WOODLEY, C., YAKRUS, M. A. 1993: Serovar determination and molecular taxonomic correlation in Mycobacterium avium, Mycobacterium intracellulare and Mycobacterium scrofulaceum: a cooperative study of the International Working Group on Mycobacterial taxonomy. Int. J. systematic Bact. 43: $482-489$

Address for correspondence

Doc. MVDr. M. Pavlas, DrSc.

State Veterinary Institute

Palackého 174

61200 Brno

Czech Republic

Phone: 420541321229 